\title{
Legislation Disharmony of Land and Business Management on State Land in Belawan Seaport
}

\author{
Muhammad Fauzie ${ }^{1}$, Sunarmi $^{2}$, Muhammad Yamin ${ }^{3}$, Maria $^{4}$ \\ \{muhammadfauzie@student.usu.ac.id ${ }^{1}$ \} \\ Universitas Sumatera Utara, Indonesia ${ }^{1,2,3,4}$
}

\begin{abstract}
This paper analyzes the causes of inefficiency in land and business management in Belawan Port and examines the legal steps that will be taken. The results of the study show two kinds of obstacles: 1) juridical barriers caused by disharmony of 3 (three) laws governing land and business management on state land, including the Basic Agrarian Law Number 5 of 1960, the State Treasury Law Number 1 of 2004, and the Shipping Law Number 17 of 2008 and 2) non-juridical constraints, including business practices at the cargo and passenger ports which are still dominated by PT Pelindo I (Persero) so that private companies cannot compete. This paper uses a normative juridical research method with a conceptual approach and legislation. In the management of fishing ports, the Belawan Fisheries General Company Branch Office has not been able to create conducive, advanced, and efficient land and business management for fisheries industry and trade. Belawan Port has difficulty competing with other foreign ports, especially in the economic, trade and industrial sectors. Another non-juridical obstacle is the Port Authority, as a government agency under the Ministry of Transportation has obtained the authority to manage state land and business activities at the cargo and passenger ports replacing PT Pelindo I (Persero). Currently, they cannot exercise their authority due to the multiple interpretations of the articles in the Shipping Law. Then, the Regulation of the Minister of Transportation as the implementing regulation of the Shipping Law contradicts the hierarchy of laws and regulations.
\end{abstract}

Keywords: Belawan Port, Pelindo, Authority, Fisheries Public Company

\section{Introduction}

The right to control the land and the livelihood of many people by the state is regulated in Article 33 of the 1945 Constitution of the Republic of Indonesia. In addition, the right to control the land by the state has also been regulated in the Basic Agrarian Law Number 5 of 1960. A seaport is one of the places related to the livelihood of many people so that it is controlled by the state. The management of the state's right to control the land of Belawan Seaport is delegated to 2 (two) State-Owned Enterprises (SOEs): PT Pelindo I (Persero) for the cargo and passenger port and the Branch Office of Fisheries Public Company in Belawan for the fishing port with a certificate of Management Right issued by the National Land Agency (NLA) of the Republic of Indonesia. Management right is the right to use the land for business, part of which is also allocated to third parties with a land-use agreement and the third parties administer a Right to Build certificate or Right to Use certificate to NLA. Until recently, the implementation of land regulations concerning Management Right is not fully conducted by PT Pelindo I (Persero) and the Branch Office of Fisheries Public Company in Belawan. The management of state land by 
State-Owned Enterprise (SOEs) is also regulated in the State Treasury Law Number 1 of 2004 and Government Regulation Number 27 of 2014 concerning State/Regional Property Management. The SOEs' inability to manage state land shows disharmony in legislations which results in inefficiencies in the management of land and business on state land in the seaport.

Business activities at Belawan Seaport are still dominated by PT Pelindo I (Persero) which seems to monopolize the business of private companies. As an SOE, the branch office of Fisheries Public Company in Belawan has not been able to create a conducive business climate due to some lawsuits submitted by private entrepreneurs concerning the regulations issued by Fisheries Public Company. One of the articles in the Shipping Law Number 17 of 2008 concerning Shipping states that land management in seaports is under the Seaport Authority, a government agency controlled by the Ministry of Transportation. However, until recently PT Pelindo I (Persero) has not yet submitted the management rights of the seaport land to the state through NLA, based on which the Seaport Authority requests, through NLA, to obtain a Management Right certificate on state land in the seaport. This occurs due to multiple interpretations of the articles in Shipping and, more surprisingly, the existence of Regulation of the Minister of Transportation as the implementing regulation of the Shipping Law.

Management of state land in seaports is regulated not only by the law made by NLA but also by other relevant regulations. The same condition also occurs in the management of state land in many sectors, e.g. in the mining, forest, and plantation sectors, where the management of state land is not only regulated by Basic Agrarian Law (BAL) and its implementing regulations but also by other laws.

This situation will result in a lot of bureaucracy and can become an obstacle for the Republic of Indonesia to compete with other countries in the era of globalization. This becomes even worse since Indonesia participates in some international agreements, the contents of which will be ratified into laws related to such agreements. The era of globalization also requires the Republic of Indonesia to immediately overcome disharmony in legislations occurring in all sectors.

Legal science appears to be very lagging behind reality, which remains marked by a profound plurality. Old and new global patterns of migration and exchanges between countries, economies, societies, and legal systems, to varying degrees and through different methods have created a transnational legal environment that is naturally plural, multi-ethnic, and multicultural, which has increasingly emerged in today's reality [1].

The problems are formulated into the following questions:

a. How is the disharmony in the legislations regarding the land and business management on state land in Belawan Seaport?

b. What are the effects of disharmony in the legislations regarding the land and business management on state land at Belawan Seaport?

c. What are the efforts to overcome the disharmony in the legislations regarding the land and business management on state land in Belawan Seaport?

\section{Research Method}

This research is a normative juridical law research by using approaches, namely conceptual approach and statutory approach. This study uses secondary data which includes primary, secondary, and tertiary legal materials relating to alternative management of the Belawan Seaport which is more effective and efficient. 


\section{Results and Discussion}

\subsection{Disharmony in the Legislations Regarding the Land and Business Management on State Land in Belawan Seaport}

The meaning of control by the state as stated in the decision of the Constitutional Court of the Republic of Indonesia Number 01/PUU-I/2003 includes 5 (five) aspects: implementing policies (beleid), administrative actions (besturdaad), regulating (regelendaad), management (beheersdaad), and supervision (toezichthoudensdaad), all of which are implemented for the greatest prosperity of the people.

Following the construction of the Constitutional Court Decision above, the control of land by the state is manifested by issuing various laws and regulations concerning land. The issuance of these laws and regulations can be categorized as the implementation of regelendaad aspect as one of the scopes in the interpretation of the meaning "controlled by the state". The issuance of these laws and regulations also becomes the characteristic of Indonesia in building a legal system, considering that Indonesia is a country with a civil law system [2].

There are at least 42 legal systems in the world, and the comparisons among these legal systems have traditionally focused on the three main legal families in the world, i.e. civil law system, common law system, and socialist law system [3].

The term 'state land' in the BAL system is not recognized, the only recognized term is 'land controlled by the state'. Article 1 and Article 2 of the BAL also state that land controlled by the state is a translation of the state's right to control over land, water, and sky. Nevertheless, many legal products still use state land as the misused term. State land has a connotation that the land belongs to the state, even though it is not really the case. The term 'state land' is basically the translation of staaddomein, so it is no longer appropriate to use, and it is better to use the term 'land controlled by the state' as regulated in the BAL. There must also be a distinction between what is called state land and government land. State land is not land attached to a land title; meanwhile, government land is the land controlled by certain government agencies and can be granted with land rights in the form of rights to use or management rights.

Land management rights are the delegation of the rights to control the state land to government agencies, including local governments, state-owned enterprises (SOEs), localowned enterprises (LOEs), PT Persero (limited liability companies), Authority Agency, and other legal entities appointed by the government. In addition to being used for the interests of the agencies themselves, the land is also intended to be granted with a certain right to a third party (Right to Use and Right to Build) if the third party's activities are related to the activities of the agencies holding the land management rights.

The holders of land management rights have the authority to plan the allocation and use of land, use the land to carry out their duties, and hand over parts of the land under their management rights to a third party and/or cooperate with a third party. The authority to hand over parts of the land to a third party and/or cooperate with a third party requires a land certificate issued by the Regional/Municipal Land Office. Submission of parts of the land to a third party that gives rise to the right to build or right to use is carried out in the form of a BOT (Build Operate Transfer) Agreement. Moreover, submission of parts of the land to a third party that gives birth to ownership right is carried out in the form of relinquishing the land by the 
holders of the land management rights. The right to build or the right to use of the land does not break the legal relationship between the holders of the land management rights and their land, but the ownership right to the land breaks the legal relationship between the holders of the land management rights and their land [4].

PT Pelindo I (Persero) Belawan manages the port of cargo and passengers at Belawan Seaport based on the Management Rights certificates issued on March 3, 1993. There are 4 (four) certificates with a total area of 289.36 ha in the name of the branch office of PT Pelabuhan Indonesia I (Persero) Belawan. It has 5 (five) subsidiaries, namely PT Prima Indonesia Logistik, PT Prima Pembangunan Kawasan, PT Prima Husada Cipta Medan, PT Prima Terminal Petikemas, PT Prima Multi Terminal, and PT Terminal Petikemas Indonesia, all of which are engaged in the seaport sector. Based on Government Regulation Number 64 of 2001, the position, duties, and authorities of the Minister of Finance as a shareholder in a limited liability company of PT Pelindo I are transferred to the Minister of State-Owned Enterprises of the Republic of Indonesia. Meanwhile, operational technical guidance is controlled by the Ministry of Transportation of the Republic of Indonesia and implemented by the Directorate General of Sea Transportation.

Belawan Fishing Port is managed by a State-Owned Enterprise with Public Company legal entity which was established under the laws of the Republic of Indonesia in accordance with Government Regulation Number 2 of 1990 concerning Prasarana Perikanan Samudera Public Company and was re-regulated by Regulation of the Government of the Republic of Indonesia Number 23 of 2000 concerning Prasarana Perikanan Samudera Public Company. Its name was changed to Perusahaan Umum Perikanan Indonesia (Indonesian Fisheries Public Company) based on Government Regulation Number 9 of 2013 concerning Indonesian Fisheries Public Company. It serves as an extension of the State's authority in providing services for public benefit (public services) based on the principles of company management in carrying out business activities in terms of optimizing the utilization of potential resources owned by the company for offices, warehousing, tourism, hotels and resorts, sports and recreation, health services, telecommunication infrastructure, and leasing and management services for assets owned and/or controlled by the company based on the principles of sound corporate management following Article 8 Paragraph (1) of Government Regulation Number 9 of 2013 concerning Indonesian Fisheries Public Company. The Branch Office of Indonesian Fisheries Public Company in Belawan has built an ice factory, supplied electric power (around 50\%), and carried out leasing and management services for land assets. Besides, it has obtained management rights on state land covering an area of 28.57 ha located in the Belawan Ocean Fishing Port Area, on Jalan Gabion Belawan, Bagan Deli Village, Medan Belawan Sub-District, Medan City, based on Point 2 of Management Rights as outlined in the Decree of the State Minister for Agrarian Affairs/Head of National Land Agency Number 198/HPL/BPN/97 issued on October 17, 1997.

PT Pelindo I and Branch Office of Fisheries Public Company in Belawan are the SOEs with the rights to manage state land in Belawan Seaport based on the Management Rights granted by the state through the National Land Agency but currently, in their relations with third parties, they are not guided by regulations regarding management rights based on BAL and its implementing regulations. PT Pelindo 1 and Branch Office of Fisheries Public Company in Belawan do not hand over their management rights to third parties (partners in carrying out their duties) either in the form of right to use or right to build with a certain time limit. After the defined time is due, all the buildings on the granted land become the rights of those who have the management rights. In managing state land, PT Pelindo I and Branch Office of Fisheries Public Company in Belawan shall refer to the Regulation of the Minister of SOEs. The 
submission of using parts of the land in the seaport included in the management rights can be granted by utilizing the land with a lease agreement. This is contradictory to the Regulation of the Minister of Home Affairs Number 1 of 1977 which states that the rights that can be given to land with management rights are Right to Build and Right to Use. Thus, this land-use agreement, in which the object of the agreement is state land that is leased, is not in accordance with the principles of the right to control by the state. Thus, by looking at the object of the management rights, i.e. state land and the public law (publicrechtelijk) characteristic of management rights, the practice of granting this lease right is not allowed. The holders of management rights on state land should not be allowed to lease the land because they are not the owners but only the managers of the delegation of authority over the right to control the land. Even the state itself is not the owner of the land but it only "controls" the land. Management rights, which essentially constitute a delegation of authority from the right to control by the state, do not stipulate the authority of the management rights holders to lease land to third parties.

The presence of Law Number 1 of 2004 concerning the State Treasury and Government Regulation Number 6 of 2006 concerning the Management of State/Regional Property has made the terms "state land" and "government land" interchangeably. This occurs because both of them use the terminology of state property and regional property interchangeably to all the assets, including the land [5].

Regulation of Minister of Finance Number 78/PMK.06/2014 governs the Implementing Procedures for Utilizing State Property.

Based on the rules regarding fixed assets such as land, if the land is purchased or acquired by SOEs by other legal means, then the way to partner with the third parties as described above is reasonable. But if the land is obtained from State Ownership Rights and is delegated with Management Rights, then land management should comply with agrarian regulations, especially the right to manage state land. A state is the manifestation of all the people of the Republic of Indonesia to control land and administer it through the state institution, the National Land Agency. State land cannot be leased because the state is not the owner of the land.

Belawan Seaport in the current era of globalization also extremely needs restructuring in all port sectors.

The government has increasingly paid attention to the logistics sector, especially since Indonesia and ASEAN countries signed the ASEAN Sectoral Integration Protocol for the Logistic Services Sector in August 2007. The agreement led to the full integration and liberalization of the logistics services sector in ASEAN. Especially in shipping business activities which are one of the pillars of logistics distribution in Indonesia, the spirit to create a healthy business competition climate is included in Law Number 17 of 2008 concerning Shipping [6].

Based on the Shipping Law, the seaport operator is Seaport Authority or Seaport Implementing Unit. The two agencies are the representatives of the government at the seaport to carry out the function of regulating, controlling, and monitoring seaport activities in Indonesia. Besides, the two agencies are technical implementing units of the Ministry of Transportation which is controlled by and responsible to the Director-General of Sea Transportation [7].

The Shipping Law clearly returns the role of the regulator to the government and PT Pelindo only becomes an operator at the seaport for one purpose, i.e. to create a competitive seaport business climate and to have more conducive business competitiveness. The Shipping Law has transformed the national seaport management system by clearly separating the operator and regulator through the presence of the Seaport Authority and Seaport Operator [8]. 
Thus, such separation automatically eliminates PT Pelindo's monopoly on commercial seaports as well as opens up the sector for the participation of other operators, including those from the private sector [8]. The Seaport Authority also acts as a government representative to provide concessions or other similar forms to the Port Business Entity (PBE) to carry out business activities at the seaport outlined in the agreement as regulated in Articles 90-92 of the Shipping Law.

Until recently, the functions and authorities of the Seaport Authority have not run according to what is mandated in the Shipping Law Number 17 of 2008. The management of State Land in the Seaport has not been released by PT Pelindo to the state through NLA and there has been no application for Management Rights by the Seaport Authority to manage the land in the seaport to the state through NLA.

\subsection{Effects of Disharmony in the Legislations Regarding the Land and Business Management on State Land at Belawan Seaport}

The Concession Agreement between Seaport Operators (Belawan Main Seaport Authority, Tanjung Priok Main Seaport Authority, Tanjung Perak Main Seaport Authority, and Makasar Main Seaport Authority) and PT Pelindo (Persero) I, II, III, and IV related to business activities and control of the existing assets ultimately stipulates the clauses by using the approach of Article 344 Paragraph (3) of the Shipping Law Number 17 of 2008 instead of the approach of Articles 90-92. Article 344 Paragraph (3) states that the determination of the term clause for the expiration of the concession implicitly shows that there is no time limit for the validity of the concession period as long as PT Pelindo belongs to the SOEs and there is no transfer of assets to the Seaport Operator at the end of the concession period. The use of the approach of Article 344 Paragraph (3) in the formulation of agreement clauses in the seaport concession agreement of PT Pelindo (Persero) I, II, III, and IV has been deemed to reduce the authority of Seaport Operator as the Seaport Authority, especially in terms of Control of Seaport Land Management Rights as well as in terms of Control of other seaport assets. As a matter of fact, the concept of Seaport Authority in the Shipping Law is as a landlord port and a controller of seaport assets obtained during the concession period. The position of PT Pelabuhan Indonesia (Persero) as the SOE in the seaport sector provides many exceptions when compared to the mandate of port concessions in the Shipping Law, Government Regulation Number 61 of 2009 concerning Seaports, and other statutory regulations. The concession agreement for seaport business activities that have been undertaken by PT Pelindo (Persero) I, II, III, and IV as signed by the Belawan Main Seaport Authority, Tanjung Priok Main Seaport Authority, Tanjung Perak Main Seaport Authority, and Makasar Main Seaport Authority with the President Director of PT Pelindo I (Persero) I, II, III, and IV on 9 and 11 November 2015, which is essentially made only to create obligations, has created uncertainty, and eventually, the provisions of port concessions as mandated in the Shipping Law cannot be fulfilled [9].

However, this factor is also caused by the Letter of the Minister of Transportation Number HK/003/1/11/Phb/2011 which appoints PT Pelabuhan Indonesia I, II, III, and IV (Persero) as the temporary implementer but without a time limit.

If carefully analyzed, the Letter of the Minister of Transportation Number HK/003/1/11/phb/2011 cannot be used as a basis by PT Pelabuhan Indonesia to continue to monopolize the seaport sector. The Letter of the Minister of Transportation contradicts Law Number 17 of 2008 [10].

According to Adolf Merkl, legal norms have two faces; one of which is upward (sourced from other higher legal norms) and the other one is downward (becoming the source and basis 
for other lower legal norms) [11]. In Stufen's theory expressed by Hans Kelsen, a lower norm applies, originates, and is based on higher norms [11].

In the hierarchy of legislation based on Article 7 Paragraph (1) Law Number 12 of 2011, the position of Law Number 17 of 2008 is higher than the ministerial letter, so the monopoly conducted by PT Pelabuhan Indonesia is not justified. Based on Articles 7 and 8 of Law Number 12 of 2011 along with their elucidation regarding this matter, Ministerial Letter is not even listed in the hierarchy of legislation even though the elucidation states that there are other forms of regulation that are recognized in addition to those stipulated in Article 7.

The fishing port managed by the Indonesian Fisheries General Company Branch Office in Belawan is also unable to create an ideal land and fishery business management together with private companies, resulting in a number of lawsuits being filed in court. Private companies must be fostered and work in ports must be supported according to the mandate of the BUMN Law Number 19 of 2003.

To overcome this problem, there are two steps that can be taken to create efficiency in ports: (i) law enforcement of regulations that are considered adequate but not yet effective; and (ii) optimizing the role of institutions that have the authority to regulate and supervise.

\section{Conclusion}

There have been obstacles in the management of land and business on state land at the cargo and passengers port managed by PT Pelindo I (Persero) and at the fishing port managed by the Branch Office of Indonesian Fisheries Public Company in Belawan which have resulted in inefficiency. The obstacles are both juridical and non-juridical obstacles. The juridical obstacles come from the disharmony of the 3 (three) laws governing the management of land and business on state land at the seaport, including Basic Agrarian Law Number 5 of 1960, State Treasury Law Number 1 of 2004, and Shipping Law Number 17 of 2008 along with Government Regulations and Ministerial Regulations as implementers of these laws. Meanwhile, nonjuridical obstacles include business practices at the cargo and passenger port which are still dominated by PT Pelindo I (Persero) which seems to have monopolized business at the seaport leading to the inability of private companies to compete. In addition, the fishing port managed by the Branch Office of Indonesian Fisheries Public Company in Belawan has also not been able to create ideal land and business management for fisheries together with private companies, resulting in a number of lawsuits submitted to the court. Private companies should be fostered and their roles at the seaport should be supported under the mandate of the SOEs Law Number 19 of 2003. Private companies together with SOEs are expected to realize development in the seaport so that they can compete with other countries in the current era of globalization, especially in the trade and industry sectors.

Another non-juridical obstacle is that Seaport Authority, which is a government agency under the Ministry of Transportation based on Shipping Law Number 17 of 2008, has obtained the authority to manage state land and business activities at the cargo and passenger port replacing PT Pelindo I (Persero). However, until now, it has not been able to carry out its authority due to multiple interpretations of the articles in the Shipping Law Number 17 of 2008 and the regulation of the minister of transportation as the implementing regulation of the shipping law which is certainly contrary to the hierarchy of legislation. As a solution to this problem, two measures can be taken aimed at creating efficiency in the seaports: (i) law enforcement against the regulations that are deemed adequate but not yet effective; and (ii) 
optimizing the role of institutions that have the authority to carry out regulation and supervision. Another effort is to conduct a judicial review to the Supreme Court on ministerial regulations that are contrary to the law. Moreover, most importantly, the Government together with the House of Representatives of the Republic of Indonesia should immediately revise the law which regulates the management of state land and businesses in seaports whose articles are not harmonious with other laws.

\section{References}

[1] W. F. Menski, Comparative law in a global context: the legal systems of Asia and Africa. Cambridge University Press, 2006.

[2] J. Asshiddiqie, "Perihal undang-undang," 2014.

[3] P. De Cruz, "Perbandingan sistem hukum common law, civil law and socialist law," Trans. N. Yusron, p. 4, 2016.

[4] U. Santoso, "Kewenangan Pemerintah Daerah dalam Penguasaan Atas Tanah," J. Din. Huk., vol. 13, no. 1, pp. 99-108, 2013.

[5] S. Julius, "Tanah Negara," Prenadamedia Group. Jakarta, 2016.

[6] Bisnis Indonesia, "Masukan Soal Liberalisme Logistik Segera Disampaikan," Bisnis Indonesia, 2007.

[7] Z. A. Rahman, "Pengusahaan Jasa Kepelabuhanan oleh PT Pelabuhan Indonesia II (Persero) pada Pelabuhan Tanjung Priok Ditinjau Dari UU No. 5 Tahun 1999 tentang Larangan Praktik Monopoli dan Persaingan Usaha Tidak Sehat." Universitas Gadjah Mada, 2015.

[8] A. Iqbal, Kepelabuhanan: Menengok Kembali UU Pelayaran. Tim Litbang JM, 2008.

[9] Nurdiansyah, "Konsesi Kepelabuhanan Dalam Perjanjian Konsesi Kegiatan Pengusahaan di Pelabuhan yang Telah Diusahakan PT Pelabuhan Indonesia I,II,III, dan IV (Persero),” J. Huk., 2017.

[10] M. Annas, "Kegiatan usaha PT. Pelabuhan Indonesia pasca lahirnya Undang-Undang Nomor 17 Tahun 2008 tentang Pelayaran dalam perspektif hukum persaingan usaha," Justitia J. Huk., vol. 1, no. 2, 2017.

[11] M. F. I. Soeprapto and A. H. S. Attamimi, Ilmu Perundang-undangan: Dasar-dasar dan pembentukannya. Kanisius, 1998. 